УДК 635.342:342:632.7:632.9

(C) 2012

Писаренко В. М., доктор сільськогосподарських наук, професор, Пономаренко С. В., аспірант*

Полтавська державна аграрна академія

\title{
ОСНОВНІ ЛИСТОГРИЗУЧІ ШКІДНИКИ КАПУСТИ БІЛОГОЛОВОЇ В ПОЛТАВСЬКІЙ ОБЛАСТІ
}

Рецензент - доктор сільськогосподарських наук, професор П. В. Писаренко

\begin{abstract}
Одержання значних урожаїв капусти білоголової високої якості неможливе без вчасного застосування заходів із захисту ії від шкідливих комах. Досліджено питання вивчення видового складу та багаторічної сезонної динаміки чисельності основних икідників капусти білоголової в Украӥні та Полтавській області. В умовах Полтавської області серед спеціалізованих шкідників білоголової капусти найбільш поширеними є капустяна совка (Mamestra brassicae L.), капустяна міль Plutella maculipennis (Curt.) та білан капустяний (Pieris brassicae L.).
\end{abstract}

Ключові слова: икідники капусти, капустяний білан, капустяна совка, капустяна міль, динаміка чисельності.

Постановка проблеми. В останні два десятиріччя завдяки зусиллям учених і практиків багатьох країн світу було обгрунтовано принципово нову концепцію інтегрованого захисту рослин, що трактується як управління динамікою популяцій шкідливих і корисних організмів на основі фітосанітарних прогнозів різної завчасності й цілеспрямованого застосування сучасних методів і засобів захисту рослин з урахуванням охорони навколишнього середовища. При цьому стратегія захисту рослин у грунтокористуванні базується на спрямуванні й узгодженні між собою заходів грунтової та рослинної гігієни, зокрема використання фітосанітарної дії сівозмін, стійких і толерантних сортів та гібридів сільськогосподарських культур, а також екологічної спрямованості хімічного методу захисту рослин на основі фітосанітарного моніторингу й сучасних методів прогнозування 3 використанням економічних порогів шкодочинності.

За такого системного підходу захист рослин від шкідливих організмів розглядається як обов'язкова підсистема сучасних систем землеробства - один із важливих, а в деякі роки - вирішальний чинник стабільності урожайності сільськогосподарських культур, підвищення якості продукції.
Виходячи 3 цього, одержання значних урожаїв капусти білоголової високої якості неможливе без вчасного застосування заходів із захисту іiі від шкідливих комах [3]. Незважаючи на значну кількість публікацій, присвячених шкідникам капусти, на сьогодні залишається недостатньо вивченими питання багаторічної динаміки їх популяцій, не розроблені методи ії прогнозування в окремих регіонах України, у тому числі й на Полтавщині. Тому питання вивчення видового складу та динаміки чисельності шкідників капусти в умовах Полтавської області $є$ актуальними.

Аналіз останніх досліджень і публікацій, у яких започатковано розв'язання проблеми. Капуста білоголова (Brassica oleracea L. var. capitata L.f. alba DC) належить до родини капустяних (Brassicaceae) роду (Brassica L. ). Капуста білоголова серед овочевих культур в Україні посідає одне з провідних місць, зокрема площа іiі нині перевищує 250 тис. га [6]. На капусті й на інших рослинах родини капустяних живиться близько 300 видів багатоїдних і спеціалізованих шкідників капусти [4]. Капуста білокачанна пошкоджується протягом усього періоду вегетації, проте найбільш небезпечними за своїми наслідками ті пошкодження, що з'являються після появи сходів та після висадки розсади в грунт. Навесні значної шкоди культурі наносять хрестоцвіті блішки, личинки капустяної мухи, гусениці капустяної молі, капустяний листоїд та ін. Влітку крім вищезгаданих видів комах рослини пошкоджують хрестоцвіті клопи, гусениці совок, біланів, личинок капустяної мухи. У другій половині літа та восени значної шкоди завдають гусениці біланів, совок, личинки та імаго капустяної попелиці.

Шкідників капусти вивчали в Аргентині, Білорусі, Вірменії [2], Грузії, Ефіопії, Італії, Канаді, Латвії [3], Молдові [1], Німеччині, Польщі, Росії, США, Швеції [4].

* Керівник-доктор сільськогосподарських наук, професор В. М. Писаренко 
Крім видового складу шкідників капусти досліджувалися біологічні особливості найбільш поширених видів, їхня шкодочинність і динаміка чисельності. В Україні шкідливих комах на капусті досліджували в Криму, Центральному Лісостепу, в Донецькій, Луганській і Харківських областях [6].

Аналіз літературних джерел свідчить, що склад основних шкідників капусти в різних регіонах має чимало спільного. Проте не лише в різних регіонах, але навіть на різних видах і сортах капусти відрізніється шкодочинність і господарське значення окремих видів. Це пов’язано, в першу чергу, 3 відмінностями життєвих циклів окремих видів фітофагів і ентомофагів у різних екологічних умовах, різною кількістю поколінь, тривалістю життя й виживання особин, синхронністю сезонних циклів розвитку фітофагів і ентомофагів.

Мета і завдання досліджень. Мета досліджень - вивчити видовий склад листогризучих шкідників капусти в Полтавській області. Літературний аналіз засвідчив, що питання про видовий склад і сезонну динаміку чисельності листогризучих шкідників капусти білоголової на Полтавщині на сьогодні лишається вкрай маловивченим. Це й послугувало достатньою підставою для проведення досліджень стосовно вивчення видового складу листогризучих шкідників капусти та їх сезонної динаміки чисельності в умовах даного регіону.

Матеріали і методи досліджень. Дослідження проводили на полях із капустою білоголовою в умовах ВАТ ім. О. Довженка Диканського району Полтавської області протягом 2009-2011 років

\section{БІБЛІОГРАФІЯ}

1. Адашкевич A. П. Энтомофаги вредителей овощных культур // Афидофаги. - М.: Колос, 1975. - 192 c.

2. Амбрасов А. Л., Болотников В. В., Бунякин В. П. Энтомофаги вредителей сада, овощных культур и картофеля. - Мн.: Наука и техника, 1981. $247 \mathrm{c}$.

3. Асякин Б. П. Особенности взаимоотношений основных вредителей капусты и их энтомофагов в консортной системе «растение - фитофаг - энтомофаг» // XII съезд Российского энтомологического обще- відповідно до загальноприйнятих методик [5].

Результати досліджень. Протягом досліджуваного періоду в цілому на полях із білоголовою капустою зустрічалося понад 30 видів комахшкідників, які належать до двох груп: багатоїдних і спеціалізованих. Серед спеціалізованих шкідників переважали капустяна совка (Mamestra brassicae L.), капустяна міль Plutella maculipennis (Curt.) та білан капустяний (Pieris brassicae L.). За досліджуваний період показники чисельності вищезгаданих комах-шкідників становили (див. табл.).

\begin{tabular}{|c|c|c|c|}
\hline \multirow[t]{2}{*}{ Назва шкідника } & \multicolumn{3}{|c|}{$\begin{array}{l}\text { Чисельність, } \\
\text { шт./ } 10 \text { рослин }\end{array}$} \\
\hline & $2009 \mathrm{p}$. & $2010 \mathrm{p}$. & $2011 \mathrm{p}$. \\
\hline $\begin{array}{c}\text { Капустяна совка } \\
\text { (Mamestra brassicae L.) }\end{array}$ & 5,3 & 7,1 & 3,9 \\
\hline $\begin{array}{c}\text { Капустяна міль } \\
\text { Plutella maculipennis } \\
\text { (Curt.) }\end{array}$ & 6,3 & 2,8 & 6,9 \\
\hline $\begin{array}{l}\text { Білан капустяний } \\
\text { (Pieris brassicae L.) }\end{array}$ & 2,7 & 2,5 & 5,3 \\
\hline
\end{tabular}

Висновки. В умовах Полтавської області серед спеціалізованих шкідників білоголової капусти найбільш поширеними є капустяна совка (Mamestra brassicae L.), капустяна міль Plutella maculipennis (Curt.) та білан капустяний (Pieris brassicae L.).

ства. - Тез. докл: СПб, 2002. - С. 23.

4. Колеснік Л. I. Шкідники і ентомофаги на капусті // Захист рослин. - 1997. - № 7. - С. 35.

5. Методика дослідної справи в овочівництві й баштанництві / [За ред. Г. Л. Бондаренка, К. І. Яковенка]. - Х: Основа, 2001. - 369 с.

6. Сероус Л. Я. Массовые размножения листогрызущих чешуекрылых вредителей капусты в Украине // Вісник ХНАУ. Серія «Ентомологіяфітопатологія». - Харків, 2004. - №5. - С. 101-104. 